\title{
Preferensi Modalitas Belajar Mahasiswa Angkatan 2016 Program Studi Pendidikan Matematika Universitas Sembilanbelas November Kolaka
}

\author{
Jahring $^{1 *}$, Chairuddin ${ }^{2}$ \\ ${ }^{1,2}$ Universitas Sembilanbelas November Kolaka \\ "jahring@usn.ac.id
}

\begin{abstract}
ABSTRAK
Penelitian ini dirancang untuk membahas informasi dan analisis tentang gaya belajar mahasiswa angkatan 2016 Program Studi Pendidikan Matematika Fakultas Keguruan dan Ilmu Pendidikan Universitas Sembilanbelas November Kolaka agar dapat menjadi pertimbangan awal bagi setiap pengajar dalam mengembangkan perkuliahan. Sedangkan variabel yang akan dilepaskan adalah gaya belajar mahasiswa (modalitas), yang terbagi menjadi dua aspek yaitu unimodal (V, A, R, K) dan multimodal, termasuk bimodal (VR, VA, VK, RK), trimodal (VRK, VAK, VAR, ARK), dan quadmodal (VARK). Hasil penelitian menunjukkan bahwa preferensi modalitas mahasiswa tergolong pada gaya belajar multimodal jenis quadmodal.
\end{abstract}

Kata Kunci: Modalitas Belajar, VARK, Unimodal, Multimodal, Gaya Belajar.

\section{ABSTRACT}

This study was designed to discuss information and analysis of the 2016 class of student learning styles. Mathematics Education Study Program Faculty of Teacher Training and Education in University of Sembilanbelas November Kolaka so that it can be an initial consideration for each teacher in developing lectures. While the variables to be released are student learning styles (modalities), which are divided into two aspects, namely unimodal $(V, A, R, K)$ and multimodal, including bimodal (VR, VA, VK, RK), trimodal (VRK, VAK, VAR, ARK), and quadmodal (VARK). The results showed that student modality preferences belong to the quadmodal multimodal learning style.

Keywords: Learning modalities, VARK, Unimodal, Multimodal, Learning Style. 


\section{PENDAHULUAN}

Modalitas belajar adalah cara informasi masuk ke dalam otak melalui indra yang kita miliki. Pada saat informasi tersebut akan ditangkap oleh indera, maka bagaimana informasi tersebut disampaikan (modalitas) berpengaruh pada kecepatan otak menangkap informasi dan kekuatan otak menyimpan informasi tersebut dalam ingatan atau memori, (Chatib, 2011). Modalitas belajar merupakan salah satu aspek penting yang harus diperhatikan oleh dosen dan mahasiswa. Dengan diketahuinya modalitas belajar, maka dosen mampu untuk memilih model perkuliahan yang tepat sesuai dengan gaya belajar mahasiswa, dan mahasiswa mampu menyusun strategi dalam belajar yang sesuai dengan gaya belajarnya sehingga mampu meningkatkan kemampuan akademiknya. Hal ini sesuai dengan pendapat Nasution (2010) bahwa kesesuaian gaya mengajar dan gaya belajar dapat mempertinggi efektivitas belajar. Lebih lanjut dikatakan Nasution (2010) bahwa gaya belajar (modalitas) adalah cara yang dengan konsisten dilakukan oleh seseorang peserta didik dalam menangkap stimulus atau informasi, cara mengingat, berpikir dan memecahkan masalah. Gaya belajar ini berkaitan dengan pribadi seseorang yang tentu dipengaruhi oleh pendidikan dan riwayat perkembangannya. gaya belajar adalah cara yang lebih kita sukai dalam melakukan kegiatan berpikir, memproses dan mengerti sesuatu informasi, (Gunawan, 2006). Gaya belajar yaitu kombinasi antara cara seseorang dalam menyerap pengetahuan dan cara mengatur serta mengolah informasi atau pengetahuan yang didapat, (Sukadi dalam Papilayah \& Huliselen, 2016). banyak ahli mendefinisikan tentang komponen gaya belajar atau modalitas belajar. De Porter \& Hernacki (2007) membagi modalitas menjadi tiga macam, yaitu visual, auditorial dan kinestetik (VAK). Menurut Neil Fleming (2006) yang membagi modalitas belajar menjadi 4 komponen, yaitu visual, auditory, read/write, dan kinestetic yang disingkat dengan VARK. Menurut Shah K. et.al. (2013) VARK mendefinisikan preferensi gaya belajar dalam hal modalitas sensorik dimana seorang siswa lebih suka mengambil informasi baru. Siswa dengan kecenderungan modalitas visual umumnya senang menggunakan media visual seperti diagram, grafik, diagram alir, dan model yang mewakili informasi visual. Pelajar auditory lebih suka informasi yang didengar, sehingga cara terbaik untuk belajar adalah diskusi, ceramah, berbicara dengan diri sendiri dan orang lain. Pelajar yang cenderung read/write lebih suka kata-kata dan buku teks sebagai cara untuk mendapatkan informasi, sehingga lebih senang buku pelajaran, kuliah catatan, selebaran, daftar dan glosarium. Selanjutnya, siswa dengan kecenderungan kinestetik menggunakan kombinasi fungsi sensorik, mereka harus merasakan atau menghayati pengalaman belajarnya, lebih suka simulasi praktek dan pengalaman nyata, pelajaran yang menekankan pada melakukan suatu kegiatan, perjalanan, pameran, sampel, studi kasus dan role play. Dalam penelitian ini membahas tentang gaya belajar VARK, karena komponen gaya belajar lebih lengkap jika dibanding dengan VAK. Adanya komponen read/write yang diharapkan mampu mengcover setiap gaya belajar yang mungkin dimiliki oleh mahasiswa. Selain itu, Gaya belajar VARK menjadi sangat penting untuk dipertimbangkan dalam meningkatkan prestasi akademik mahasiswa karena gaya belajar VARK dapat menciptakan lingkungan belajar yang menarik dan meransang indera dalam belajar, (Othman \& Amiruddin, 2010).

Berdasarkan hasil observasi awal pada beberapa mata kuliah di angkatan 2016 Program

Studi Pendidikan Matematika Fakultas Keguruan dan Ilmu Pendidikan Universitas 
Sembilanbelas November Kolaka diperoleh bahwa pemilihan model pembelajaran, strategi perkuliahan, ataupun metode perkuliahan yang dilakukan oleh sebagian besar dosen belum berdasarkan gaya belajar yang dimiliki oleh mahasiswa. Sebagian besar pengembangan model perkuliahan yang dirangkum dalam suatu Rencana Pembelajaran Semester (RPS) hanya berdasarkan pada penggunaan media pembelajaran, bahkan tidak sedikit melaksanakan perkuliahan tanpa memanfaatkan media pembelajaran, model, metode dan strategi pembelajaran. Padahal ada beberapa model pembelajaran yang cocok dengan gaya belajar mahasiswa. Misalnya mind mapping (read/write dan kinestetik), TGT (Audio, visual, dan kinestetik), dan berbagai model pembelajaran lainnya. Hal ini menyebabkan kurang efektifnya atau bahkan tidak efektifnya proses perkuliahan, sehingga pencapaian tujuan perkuliahan tidak maksimal. Hal ini secara khusus ditunjukkan dengan adanya beberapa mahasiswa yang tidak lulus UTS maupun UAS. Secara umum ditunjukkan dengan indeks prestasi (IP) yang tergolong rendah. Secara kuantitatif ditunjukkan bahwa dari 74 mahasiswa Program Studi Pendidikan Matematika Angkatan 2016, hanya sekitar 45 orang (60,81\%) yang memiliki Indeks Prestasi Kumulatif (IPK) lebih dari 3,00. Selebihnya 29 orang $(39,19)$ yang memiliki Indeks Prestasi Kumulatif (IPK) kurang dari 3,00.

Penelitian serupa telah dilakukan oleh Ummu Kalzum Malik, et al. (2017). Hasil penelitiannya menunjukkan gaya belajar visual sebesar 1,4\%, Aural sebesar 29\%, read/write sebesar 24,6\%, dan kinestetik sebesar 32\%. Untuk gaya belajar multimodal sebesar 13\%. Selanjutnya juga mengamati aplikasi gaya belajar yang dilakukan mahasiswa yang sesuai dengan gaya belajarnya. Berbeda dengan penelitian ini, yang bertujuan untuk memberikan informasi kepada mahasiswa tentang gaya belajar yang dimilikinya sehingga mampu belajar sesuai dengan gaya belajarnya. Selain itu, juga memberikan informasi kepada dosen tentang gambaran gaya belajar di dalam kelas kuliah. Sehingga mampu merencanakan model pembelajaran sesuai gaya belajar yang ada.

Oleh karena itu, rencana penelitian ini adalah untuk menggali dan menyajikan informasi dan analisis tentang gaya belajar mahasiswa angkatan 2016 Program Studi Pendidikan Matematika Fakultas Keguruan dan Ilmu Pendidikan Universitas Sembilanbelas November Kolaka sehingga menjadi pertimbangan awal bagi setiap dosen dalam mengembangkan perkuliahan. Preferensi modalitas belajar yang akan ditampilkan adalah terbagi menjadi dua aspek yaitu unimodal (V,A,R,K), dan multimodal meliputi bimodal (VR, VA, VK, RK), trimodal (VRK, VAK, VAR, ARK), dan quadmodal (VARK), (Dobson, 2010).

\section{PROSEDUR PENELITIAN}

Penelitian ini merupakan penelitian kualitatif dengan desain deskriptif, yaitu penelitian yang memberi gambaran secara cermat mengenai indivisu atau kelompok tertentu tentang keadaan dan gejala yang terjadi, (Koentjaraningrat, 1993). Menurut Sugiyono (2009) penelitian kualitatif adalah suatu metode penelitian yang berlandaskan pada filsafat post positivisme, digunakan untuk meneliti pada kondisi objek yang alamiah dimana peneliti adalah sebagai instrumen kunci, pengambilan sampel sumber data dilakukan secara purposive, teknik pengumpulan dengan triangulasi, analisis data bersifat induktif/kualitatif, dan hasil penelitian kualitatif lebih menekankan makna dari pada generalisasi. 
Subyek penelitian ini adalah seluruh mahasiswa angkatan 2016 Program Studi Pendidikan Matematika Fakultas Keguruan dan Ilmu Pendidikan (FKIP) Universitas Sembilanbelas November (USN) Kolaka, yang terdiri dari dua kelas sebanyak 74 orang yang saat ini berada di semester V tahun akademik 2018/2019. Menurut Fathoni (2006) menyatakan Prosedur pengumpulan data merupakan kegiatan yang dilakukan oleh peneliti untuk mengumpulkan data yang mana data tersebut sangat berguna atau mempunyai peranan yang sangat penting dalam penelitian. Dalam penelitian ini, teknik pengumpulan data yang digunakan yaitu teknik observasi dan teknik angket. Instrumen pendukung dalam penelitian ini adalah kuisioner VARK yang berisi 16 pertanyaan baku terkait modalitas belajar yang merupakan kuisioner baku yang diadopsi dari The VARK Questionnaire Version 7.1 yang disadur dari www.vark-learn.com. Setiap nomor pernyataan dalam kuisioner mempunyai empat opsi jawaban, masing-masing opsi sudah mewakili indikator VARK itu sendiri, yaitu visual, auditory, read/write dan kinestetik. Jika hanya memilih satu opsi maka cenderung gaya belajar unimodal dan jika lebih dari satu maka cenderung gaya belajar multimodal. Analisis data yang digunakan dalam penelitian ini adalah analisis deskriptif, yaitu menggambarkan atau mendeskripsikan semua hasil penelitian. Adapun variabel yang akan ditampilkan adalah gaya belajar mahasiswa (modalitas), yang terbagi menjadi dua aspek yaitu unimodal (V, A, R, K) dan multi modal, meliputi bimodal (VR, VA, VK, RK), trimodal (VRK, VAK, VAR, ARK), dan quadmodal (VARK).

\section{HASIL DAN PEMBAHASAN}

Berdasarkan hasil analisis data, peneliti menemukan preferensi modalitas belajar mahasiswa angkatan 2016 Program Studi Pendidikan Matematika Universitas Sembilanbelas November Kolaka, baik kecenderungan unimodal (V, A, R, K) maupun kecenderungan multimodal (bimodal, trimodal, quadmodal). Secara rinci disajikan dalam Tabel 1 berikut.

\begin{tabular}{cccc}
\multicolumn{4}{c}{ Tabel 1. Preferensi Modalitas Belajar Mahasiswa } \\
\cline { 1 - 3 } Modalitas Belajar & \multicolumn{2}{c}{ Jenis Kelamin } & Total \\
\cline { 1 - 3 } Unimodal & Laki-Laki (\%) & Perempuan (\%) & $(\%)$ \\
\cline { 1 - 3 } V & $0(0 \%)$ & $0(0 \%)$ & $0(0 \%)$ \\
A & $2(28,57 \%)$ & $5(71,43 \%)$ & $7(38,89 \%)$ \\
R & $0(0 \%)$ & $2(100 \%)$ & $2(11,11 \%)$ \\
K & $4(44,44 \%)$ & $5(55,56 \%)$ & $9(50 \%)$ \\
\hline Total & $\mathbf{6 ( 3 3 , 3 3 \% )}$ & $\mathbf{1 2 ( 6 6 , 6 7 \% )}$ & $\mathbf{1 8}$ \\
\hline Multimodal & & & \\
\hline Bimodal & $2(50 \%)$ & $2(50 \%)$ & $4(7,14 \%)$ \\
Trimodal & $5(26,32 \%)$ & $14(73,68 \%)$ & $19(33,93 \%)$ \\
Quadmodal & $7(21,21 \%)$ & $26(78,79 \%)$ & $33(58,93 \%)$ \\
\hline Total & $\mathbf{1 4 ( 2 5 \% )}$ & $\mathbf{4 2 ( 7 5 \% )}$ & $\mathbf{5 6}$ \\
\hline
\end{tabular}

Berdasarkan Tabel 1, dapat dikatakan bahwa mahasiswa angkatan 2016 Program Studi Pendidikan Matematika Universitas Sembilanbelas November Kolaka dengan jumlah 74 orang yang terdiri dari 20 laki-laki dan 54 perempuan lebih dominan dengan modalitas belajar jenis multimodal, sebanyak 56 orang $(75,68 \%)$ terdiri dari 4 orang $(7,14 \%)$ bimodal, 19 orang $(33,93 \%)$ trimodal, dan 33 orang $(58,93)$ quadmodal. Jika dibandingkan dengan preferensi modalitas belajar jenis unimodal yang hanya 18 orang $(24,32 \%)$ terdiri dari preferensi auditori 
sebanyak 7 orang $(38,89 \%)$, preferensi read/write sebanyak 2 orang $(11,11 \%)$, dan preferensi kinestetik sebanyak 9 orang (50\%) yang jumlahnya lebih sedikit. Secara rinci dibuat dalam bentuk diagram batang seperti pada Gambar 1 berikut.

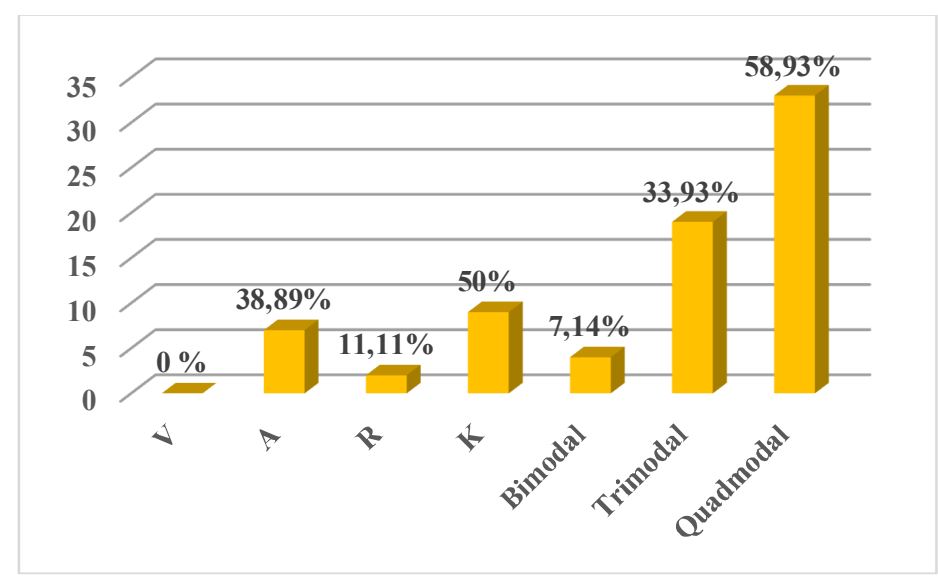

Gambar 1. Diagram Batang Modalitas Belajar Mahasiswa

Dengan adanya data tentang preferensi modalitas belajar mahasiswa ini, dosen mampu untuk mengembangkan strategi perkuliahan dalam meningkatkan prestasi akademik mahasiswa. Menurut Shah K. et.al. (2013), bahwa belajar tidak akan pernah menjadi beban jika penyajian pembelajaran disajikan dengan gaya yang disukai oleh siswa dan jika belajar dibuat menyenangkan, maka prestasi akademik akan meningkat. Oleh karena itu, menjadi tanggung jawab setiap dosen untuk memahami gaya belajar setiap mahasiswa dalam menentukan strategi pemrkuliahan yang tepat. Selain itu, gambaran data yang diberikan ini dapat menjadi referensi setiap pendidik pada umumnya, dan dosen di Program Studi Pendidikan Matematika Fakultas Keguruan dan Ilmu Pendidikan Universitas Sembilanbelas November Kolaka pada khususnya untuk membantu mengatasi kecenderungan untuk memperlakukan semua mahasiswa dengan cara yang sama, memberikan motivasi bagi guru untuk selalu mengembangkan model pembelajaran, selalu berinovasi dalam pembelajaran yang mampu meningkatkan prestasi akademik.

\section{SIMPULAN}

Modalitas belajar mahasiswa angkatan 2016 Program Studi Pendidikan Matematika Universitas Sembilanbelas November Kolaka cenderung memiliki gaya belajar multimodal jenis quadmodal dengan persentase terbesar yaitu 58,93\% (33 orang). Artinya bahwa sebagian besar mahasiswa belajar dengan gaya belajar yang mengkombinasikan visual, auditori, read/write dan kinestetik. Sehingga jika ingin meningkatkan prestasi akademik mahasiswa, sebaiknya menggunakan model pembelajaran yang melingkup keempat gaya belajar yang dimaksud. Dalam pelaksanaannya, model hanya melingkup satu atau dua gaya belajar saja. Pertemuan berikutnya melin gaya belajar lainnya, dan seterusnya. 


\section{DAFTAR PUSTAKA}

Chatib, Munir. (2011). Gurunya Manusia: Menjadikan Semua Anak Istimewa dan Semua Anak Juara. Bandung: Mizan Pustaka.

Damayanti, A.K \& Pratitis, N.T. (2012). Gaya Belajar Ditinjau dari Tipe Kepribadian dan Jenis Kelamin. Persona, Jurnal Psikologi Indonesia. Vol. 1, No. 2, September. Pp. 88-98.

De Porter, Bobbi, \& Hernacki, Mik. (2007). Quantum Learning. Diterjemahkan oleh Alwiyah Abdurrahman. Bandung: Kaifa PT. Mizan Putra.

Dobson, J.L. (2010). A Comparison Between Learning Style Preference and Sex, Status, and Course Performance. Advances in Physiology Education, 34, pp. 197-204. doi:10.1152/advan.00078.2010.

Fathoni, Abdurrahman. (2006). Sumber Daya Manusia, Bandung: Rineka Cipta

Fleming, Neil D \& David Baume. (2006). Learning Style Again: VARKing up the right tree!. Educational Developments SEDA Ltd. Issue 7.4. (4-7).

Fleming, N. D. (2011). VARK a Guide to Learning Style. (C) Copyright Version 7.1 held by Neil D. Fleming, Christchurch, New Zealand. http://vark-learn.com/the-vark-questionnaire/.

Gunawan, Adi W. (2006). Genius Learning Strategy Petunjuk Praktis untuk Menerapkan Accelerated Learning. Jakarta: Pustaka Utama.

Koentjaraningrat. (1993). Metode-metode Penelitian Masyarakat. Jakarta: PT. Gramedia Pustaka Utama.

Malik, U.K., Emilia, O., Rahayu, R.G., Ibrahim, J. 2017. Aplikasi Gaya Belajar pada Kegiatan Belajar Mandiri Mahasiswa Tahun Pertama Fakultas Kedokteran Universitas Muhammadiyah Makassar. Jurnal Berkala Ilmiah Kedokteran dan Kesehatan MAGNA MEDICA. Vol. 1 No. 4 Agustus 2017, 25-32.

Nasution. (2010). Berbagai Pendekatan dalam Proses Belajar dan Mengajar. Jakarta: Bumi Aksara.

Othman, N. \& Amiruddin, M.H. (2010). Different Perspectives of Learning Style from VARK Model. International Conference on Learner Diversity 2010. Procedia Social and Behavioral Sciences 7(C) (2010) 652-660. doi:10.1016/j.sbspro.2010.10.088.Published by Elsevier Ltd.

Papilayah, J.O., \& Huliselen, N. (2016). Identifikasi Gaya Belajar Mahasiswa. Jurnal Psikologi Undip Vol. 15 No. 1 April 2016, 56-63.

Shah,K., Ahmed, J., Shenoy N., Srikant N. (2013). How different are students and their learning style?. International Journal of Research in Medical Sciences. Int J Med Sci. 2013 Aug: 1(3): 101-104. doi:10.5455/2320-6012.ijrms20130808.

Sugiyono. (2009). Metode Penelitian Kuantitatif dan Kualitatif. Bandung: CV. Alfabeta. 